\title{
Os concílios provinciais de Goa: reflexóes sobre o impacto da "Reforma Tridentina" no centro do império asiático português $(1567-1606)^{*}$
}

\author{
Patricia Souza de Faria ${ }^{* *}$
}

\section{RESUMO}

O objetivo deste artigo é a análise das resoluções dos concílios provinciais de Goa (celebrados em 1567, 1575, 1585, 1592 e 1606), investigadas no âmbito das transformaçóes religiosas ocorridas no início da Era Moderna, isto é, no bojo do que foi denominado Contrarreforma ou "Reforma Tridentina". Analisa-se o possível impacto dos decretos do Concílio de Trento sobre as atas dos mencionados concílios provinciais e nas Constituiçóes do Arcebispado de Goa (1568).

Palavras-chave: império asiático português; Goa; catolicismo; Concílio de Trento; Contrarreforma.

\section{ABSTRACT}

This article analyzes the resolutions issued by the Provincial Councils of Goa (1567, 1575, 1585, 1592 and 1606) from the perspective of the religious transformations that took place at the beginning of the Modern Era, i.e., at the peak of what was denominated the CounterReformation or Tridentine Reform. It also examines the likely impact of the decrees issued by the Council of Trent on the minutes of the aforementioned Provincial Councils, and on the Constituiçóes do Arcebispado de Goa (Constitutions of the Goa Archbishopric), of 1568.

Keywords: Asian Portuguese empire; Goa; catholicism; Council of Trent; Counter-Reformation.

Artigo recebido em 31 de março de 2013 e aprovado em 15 de outubro de 2013.

Artigo - DOI - http://dx.doi.org/10.1590/2237-101X015027002

*Agradeço o auxílio à pesquisa concedido pelo CNPq por meio do Edital Universal - 2012.

** Doutora em história pela Universidade Federal Fluminense, professora adjunta da Universidade Federal Rural do Rio de Janeiro. E-mail: patricia@carvano.com.br. 
O objetivo deste artigo é a análise das resoluçóes dos concílios provinciais de Goa (celebrados em 1567, 1575, 1585, 1592 e 1606), investigadas no âmbito das transformaçôes religiosas ocorridas no início da Era Moderna, isto é, no bojo do que foi denominado Reforma Católica, Contrarreforma ou Reforma Tridentina. ${ }^{1}$ Um dos debates sobre as mudanças do catolicismo moderno consistiu na avaliação do impacto das decisôes assumidas no Concílio de Trento (1545-1563). Com efeito, investigam-se as possíveis reverberaçôes das orientaçóes tridentinas nas atas dos mencionados concílios provinciais e nas Constituiçóes do Arcebispado de Goa (1568).

As reflexôes e práticas associadas à reforma do catolicismo moderno, que se manifestaram primordialmente no continente europeu, projetaram-se sobre determinadas regiốes situadas fora dos limites geográficos do Velho Mundo, em decorrência das conexóes históricas que uniram reinos e povos da Península Ibérica e do ultramar, como foi o caso de Goa. ${ }^{2}$ Esta investigação inspira-se nas proposiçóes de R. Hsia, autor que denunciou uma das limitaçôes da historiografia dedicada ao estudo da Reforma Católica: negligenciar a história do catolicismo desenvolvido em espaços não europeus. ${ }^{3}$

Consideramos que os textos dos concílios provinciais de Goa denotam a rápida recepçáo das determinaçôes formuladas no Concílio de Trento, bem como elucidam esforços associados à introdução da disciplina cristã â nos espaços asiáticos administrados pelos agentes da Coroa portuguesa no Oriente, especialmente em Goa. ${ }^{5}$ Esta regiáo — situada no litoral oci-

\footnotetext{
${ }^{1}$ Sobre as denominações atribuídas à Reforma Católica e seus sentidos subjacentes: O’MALLEY, John W. Trent and all that: renaming Catholicism in the Early Modern Era. Cambridge, Massachusetts: Harvard University Press, 2002; PROSPERI, Adriano. El Concilio de Trento: una introducción histórica. Valladolid: Junta Castilla-Leon, 2008; TALLON, Alain. Le Concile de Trente. Paris: Cerf, 2010; BRADY JR., Thomas A. Confessionalization: the career of a concept. In: HEADLY et al. (Org.). Confessionalization in Europe. Aldershot; Burlington: Ashgate, 2004. p. 1-20; PRODI, Paolo. Christianisme et monde moderne. Paris: Seuil; Gallimard, 2006; JEDIN, Hubert. História del Concilio de Trento. Pamplona: Ediciones Universidad de Navarra, 1972.

${ }^{2}$ Sobre tais conexões históricas: GRUZINSKI, Serge. Les mondes mêlés de la monarchie catholique et autres connected histories. Annales: Histoire, Sciences Sociales, Paris, v. 56, n. 1, p. 85-117, jan./fev. 2001; SUBRAHMANYAN, Sanjay. Connected histories: notes towards a reconfiguration of Early Modern Eurasia. In: LIEBERMAN, Victor (Ed.). Beyond binary histories. Ann Arbor: The University of Michigan Press, 1997. p. 289-315.

${ }^{3}$ A respeito do impacto da "renovação do catolicismo" em escala mundial, ver: HSIA, Ronnie Po Chia. The world of Catholic renewal. 1540-1770. Cambridge: Cambridge University Press, 1998. p. 1-6.

${ }_{4}^{4}$ Acerca da cristianização de Goa, consultar os importantes trabalhos de: TAVARES, Célia Cristina da Silva. Jesuitas e inquisidores em Goa. Lisboa: Roma Editora, 2004 e XAVIER, Ângela Barreto. A invenção de Goa. Poder imperial e conversôes culturais nos séculos XVI e XVII. Lisboa: ICS, 2008.

${ }^{5}$ Os decretos deveriam ser aplicados na Província Eclesiástica em questão (o Arcebispado de Goa), que era delimitada pela região situada de "Diu até o Cabo Camorim". Alguns decretos trataram especificamente de Ormuz, Malaca ou da Província do Norte, enquanto outros foram concebidos para regióes genericamente descritas como "cidades e povoaçóes de cristãos" (situadas em terras que reconheciam a autoridade da Coroa portuguesa) ou como portos do Estado da Índia. Conforme: Primeiro Concílio Provincial de Goa, 1567, transcrito em: REGO, António da Silva (Org.). Documentos para história das missóes do padroado português no Oriente. Lisboa: Agência Geral do Ultramar, 1995. v. 10. Doravante, para se referir às atas deste primeiro
} 
dental da Índia — foi conquistada pelos portugueses em 1510 e se tornou, progressivamente, o centro do império luso-asiático. ${ }^{6}$ Transformou-se na sede do bispado criado em $1534 \mathrm{e}$, em seguida, do Arcebispado de Goa, em 1558 . $^{7}$

Neste artigo, abordaremos inicialmente a recepção dos decretos tridentinos na Europa, com ênfase no caso português e, em seguida, faremos uma breve comparação com a recepção de tais decretos nos espaços coloniais ibéricos. Após essas consideraçóes gerais, trataremos da incorporação das orientaçôes tridentinas nas atas dos concílios provinciais de Goa, por meio de dois procedimentos. O primeiro deles destaca a alusão direta aos decretos tridentinos, enquanto o segundo consiste em demonstrar como os principais eixos da "Reforma Tridentina" (papel dos bispos, da reforma pastoral, atenção à formação dos sacerdotes) foram abordados nas atas dos concílios provinciais sediados em Goa. Por fim, mencionaremos outras matrizes que inspiraram a formulação dos decretos dos concílios de Goa, especialmente os contidos na Ação $2^{2}$ das atas conciliares.

\section{A recepção dos decretos tridentinos}

Antes de analisar os textos dos concílios provinciais de Goa, cabe mencionar que a historiografia reconhece o quanto a cronologia da adoção das orientaçóes tridentinas foi variável, tanto no continente europeu ${ }^{8}$ como nos espaços coloniais ibéricos. A França, por exemplo, admitiu apenas tardiamente os decretos tridentinos.' Similarmente, as divisóes políticas e confessionais no Império Habsburgo dificultaram a aceitação oficial das decisóes do Concílio de Trento pelo imperador. Cabe ressaltar que, em 1555, a frágil paz de Augsburgo sancionou o princípio cujus regio, ejus religio, o que redundou em um direito religioso nos espaços do império que, em princípio, toleraria as diferentes confissões religiosas (católica, luterana, calvinista). ${ }^{10}$

O reconhecimento dos decretos foi rápido nos estados italianos, porém, com o passar

concílio, citar-se-á: DHMPPO, v. 10.

${ }^{6}$ SANTOS, Catarina Madeira. Goa é a chave de toda a Índia. Lisboa: CNCDP, 1999.

${ }^{7}$ Sobre o arcebispado de Goa, ver: JACQUES, Roland. De Castro Marim à Fä̈fo: naissance et développement du padroado portugais d'Orient des origines à 1659. Lisboa: Fundação Calouste Gulbenkian, 1999; XAVIER, Ângela Barreto. A organização religiosa do primeiro Estado da Índia. Notas para uma investigação. Anais de História de Além-Mar, Lisboa, n. 5, p. 27-59, 2004; FARIA, Patricia Souza de. A conquista das almas do Oriente: franciscanos, catolicismo e poder colonial português em Goa. Rio de Janeiro: 7Letras, 2013; NAZARETH, Casimiro C. de. Mitras lusitanas do Oriente. Nova Goa: Imprensa Nacional, 1887; Biblioteca Nacional de Lisboa, cód. 176, Memórias para a história eclesiástica do Arcebispado de Goa e seus sufragâneos.

${ }^{8}$ Uma síntese sobre a questão pode ser consultada em: MULLET, Michael. A Contra-Reforma. Lisboa: Gradiva, 1985.

${ }^{9}$ PROSPERI, Adriano. El Concilio de Trento, op. cit. p. 88-92; Discours sur la récéption du Concile de Trente en France. Paris: s.n., 1615.

${ }^{10}$ Ibid., p. 88-92. 
do tempo, a aceitação do Concílio de Trento foi compreendida como algo que sobrepujava a mera adoçáo dos decretos, pois foi entendida como a adesão dos Estados à política católica intransigente e à preeminência papal. ${ }^{11}$ Cabe mencionar o conflito entre a República de Veneza e o papado, em 1606, associado à limitação dos privilégios eclesiásticos da Sereníssima pelo Pontífice. Veneza moveu uma intensa panfletagem, conduzida especialmente por Paolo Sarpi, que redigiu a Historia del Concilio Tridentino (publicada em Londres, em 1619), tratada como sinal da decadência da Igreja, reflexo de interesses políticos e não de questóes efetivamente religiosas. ${ }^{12}$

No Velho Mundo, os reinos de Portugal e da Espanha estiveram entre os primeiros a reconhecer os decretos tridentinos. ${ }^{13} \mathrm{O}$ Concílio de Trento foi concluído em 4 de dezembro de 1563, aprovado em 26 de janeiro de 1564 pelo papa Pio IV em Consistório secreto, confirmado pela bula Benedictus Dei, de três de junho de 1564. No mesmo dia, o breve Sacri Tridentini Concili foi endereçado ao soberano de Portugal, ${ }^{14}$ com o envio de um exemplar dos decretos instituídos no mencionado concílio. O cardeal d. Henrique e d. Bartolomeu dos Mártires (arcebispo de Braga) ordenaram quatro edições dos decretos tridentinos no ano de 1654: três em português e uma em latim. ${ }^{15}$

A cerimônia de recepção dos decretos tridentinos ocorreu em Portugal em 7 de setembro de 1564, além de terem sido expedidas cartas régias aos prelados do Reino e das conquistas ultramarinas, com a remessa do volume impresso em Lisboa, contendo a bula e decretos; estabeleceu-se que houvesse solene publicação dos decretos nas respectivas regiôes para as quais foram remetidas as missivas. ${ }^{16}$ Logo, os decretos conciliares foram adotados e integrados no corpo legislativo de Portugal, durante a regência do cardeal d. Henrique. ${ }^{17}$ Das capitais ibéricas, os decretos do Concílio de Trento foram disseminados aos respectivos espaços coloniais. ${ }^{18}$

O império do Oriente foi a porção do ultramar português em que foram mais visíveis os impactos do Concílio de Trento, no âmbito normativo. Como salientou Boschi, as reuniôes

\footnotetext{
${ }^{11}$ TALLON, Alain. Le Concile de Trente, op. cit. p. 86.

${ }^{12}$ O'MALLEY, John. Trent and all, op. cit. p. 31.

${ }^{13}$ PROSPERI, Adriano. El Concilio de Trento, op. cit, p. 87-88, 96.

${ }^{14} \mathrm{O}$ regente $\mathrm{d}$. Henrique governava naquele período.

${ }^{15}$ FERNANDES, Maria de Lourdes Correia. Da reforma da Igreja à reforma dos cristãos: reformas, pastoral e espiritualidade. In: AZEVEDO, Carlos Moreira (Dir.). História religiosa de Portugal. Lisboa: Círculo dos Leitores, 2000. v. 2, p. 25; CAETANO, Marcello. Recepção e execução dos decretos do Concílio de Trento em Portugal. Revista da Faculdade de Direito da Universidade de Lisboa, Lisboa, v. 19, p. 7-87, 1965; SILVA, Amélia Maria Polónia da Silva. Recepção do Concílio de Trento em Portugal: as normas enviadas pelo cardeal d. Henrique aos bispos do reino, em 1553. Revista da Faculdade de Letras - História, Porto, II série, v. 2, p. 133-143, 1990.

${ }^{16}$ CAETANO, Marcello. Recepção e execução dos decretos do Concílio de Trento em Portugal, op. cit. p. 7-87.

${ }^{17}$ SILVA, Amélia Maria Polónia da Silva. Recepção do Concílio de Trento em Portugal, op. cit. p. 133-143.

${ }^{18}$ PROSPERI, Adriano. El Concilio de Trento, op. cit. p. 88.
} 
episcopais de Goa foram as que mais se destacaram no império luso. ${ }^{19} \mathrm{O}$ resultado dessas reunióes episcopais foi a produção de decretos que evidenciam o esforço de incorporação das orientações tridentinas. Ademais, a própria regularidade dos concílios celebrados em Goa demonstra a consonância como uma das orientações do Concílio de Trento (sessão XXIV), que restabeleceu a realização de concílios provinciais nos lugares em que tivessem sido abolidos, com regularidade trienal. ${ }^{20}$ Essa decisão tridentina foi cumprida no Reino de Portugal, em 1566, ano em que foram realizadas as reunióes de Lisboa e de Braga. Um ano depois, ocorreram em Évora e em Goa. ${ }^{21}$

Comparativamente, o caso brasileiro foi bastante distinto da experiência da Igreja em Goa, pois não temos provas concretas de compilaçóes de legislação eclesiástica nos séculos XVI e XVII. ${ }^{22} \mathrm{O}$ primeiro bispado criado na América portuguesa foi estabelecido em 1551, ao passo que a realização de sínodos e concílios provinciais precisou aguardar 156 anos, apesar de tentativas anteriores de celebração das reuniōes episcopais em território brasileiro. ${ }^{23}$ De modo que, apenas no início do século XVIII, concretizou-se o esforço de d. Sebastiāo Monteiro da Vide, arcebispo de Salvador da Bahia, de sistematizar e ajustar as diretrizes tridentinas às vicissitudes do Brasil colonial. Em 1704, concluiu-se o Regimento do Auditório Eclesiástico da Arquidiocese da Bahia e, em 1707, foi celebrada a reunião dos prelados e a elaboração das Constituiçóes primeiras do Arcebispado da Bahia. ${ }^{24}$

Portanto, a intensa atividade legislativa do Arcebispado de Goa não foi desprezível, visto que a regularidade de seus concílios provinciais se destaca, ao serem comparados com as experiências legislativas homólogas desenvolvidas em outros espaços coloniais portugueses. Em decorrência dessa intensa atividade legislativa, optou-se por realizar uma análise de caráter normativo, de modo que as atas dos cinco concílios fossem apreciadas em conjunto, com o objetivo de apreender as questóes gerais que deram forma aos textos conciliares e as suas preocupaçóes centrais. Ao serem abordados os textos conciliares em conjunto, pretendemos inicialmente destacar os esforços de ajustamento da Igreja local aos parâmetros instituídos no "centro" (em Trento e em Portugal). E, em um segundo momento, considerar como as vicissitudes locais, ligadas à cristianização de Goa, também foram significativas na definição

\footnotetext{
${ }^{19}$ BOSCHI, Caio. Estruturas eclesiásticas e inquisição. In: BETHENCOURT, Francisco; CHAUDHURI, Kirti. História da expansão portuguesa. Navarra: Círculo de Leitores e Letras, 1998. v. 2, p. 429-452.

${ }^{20}$ FEITLER, Bruno; SOUZA, Evergton Sales (Ed.). Constituiçôes Primeiras do Arcebispado da Bahia. São Paulo: Edusp, 2010. p. 36. Consultar: Sacrosanto, e ecumênico Concílio de Trento, em latim e portuguez. Lisboa: Off. de Francisco Luiz Ameno, 1781. t. 2, sessão XXIV, Decreto da Reforma, Capítulo II, p. 267 — que estabeleceu a reunião de concílios provinciais a cada triênio e anualmente, a de sínodos diocesanos.

${ }^{21}$ REGO, Antônio da Silva. A liberdade religiosa e o I Concílio Provincial de Goa (1567). Memórias da Academia das Ciências de Lisboa. Lisboa: Academia das Ciências, 1967. t. 10, p. 41-55, p. 42.

${ }^{22}$ BOSCHI, Caio. Estruturas eclesiásticas e inquisição, op. cit. p. 429-452.

${ }^{23}$ FEITLER, Bruno; SOUZA, Evergton Sales. Constituiçôes Primeiras do Arcebispado da Bahia, op. cit. p. 37. ${ }^{24}$ BOSCHI, Caio. Os escritos de d. frei Manuel da Cruz e as Constituiçóes Primeiras do Arcebispado da Bahia. In: FEITLER, Bruno; SOUZA, Evergton Sales (Org.). A Igreja no Brasil: normas e práticas durante a vigência das Constituiçóes Primeiras do Arcebispado da Bahia. São Paulo: Unifesp, 2011. p. 399-400.
} 
de determinados decretos conciliares.

\section{Os concílios provinciais de Goa e a incorporação dos decretos tridentinos}

Os textos dos concílios provinciais de Goa dividem-se nas seguintes partes. A Ação $1^{\text {a }}$ contém a apresentação do concílio e seus objetivos, bem como a Profissão de Fé tridentina. A Ação 2a aborda a conversão dos gentios e dos infiéis, além de tratar dos cristãos neófitos. Em geral, o tratamento de assuntos eclesiásticos e do culto divino predominou na Ação 3a , ao passo que os decretos concernentes à reforma da Igreja concentram-se na Ação 4⿳⺈. Essa distribuição não se verificou nas atas do Terceiro Concílio Provincial, cuja Ação $3^{\underline{a}}$ foi dedicada exclusivamente aos cristãos de São Tomé (quadro 1).

Quadro 1

Concílios Provinciais de Goa

\begin{tabular}{|c|c|c|c|c|c|}
\hline Ano & $\begin{array}{c}\text { Açáo 1 } \mathbf{1}^{\mathrm{a}} \\
\text { (decretos) }\end{array}$ & $\begin{array}{c}\text { Açáo 2 }{ }^{\mathrm{a}} \\
\text { (decretos) }\end{array}$ & $\begin{array}{c}\text { Açáo 3a } \\
\text { (decretos) }\end{array}$ & $\begin{array}{c}\text { Açáa 4 }{ }^{\mathrm{a}} \\
\text { (decretos) }\end{array}$ & $\begin{array}{c}\text { Açáa 5a } \\
\text { (decretos) }\end{array}$ \\
\hline 1567 & $\begin{array}{l}\text { Profissão de } \\
\text { Fé /Apresen- } \\
\text { taçáo } \\
\text { (1) }\end{array}$ & $\begin{array}{l}\text { Conversão dos infiéis } \\
\text { e "novamente conver- } \\
\text { tidos" } \\
(47)\end{array}$ & $\begin{array}{l}\text { Reforma da } \\
\text { Igreja } \\
\text { (35) }\end{array}$ & $\begin{array}{l}\text { Reforma dos } \\
\text { costumes } \\
\text { (33) }\end{array}$ & - \\
\hline 1575 & $\begin{array}{l}\text { Profissáo de } \\
\text { Fé /Apresen- } \\
\text { taçáo } \\
\text { (3) }\end{array}$ & $\begin{array}{l}\text { Conversão dos infiéis } \\
\text { e "novamente conver- } \\
\text { tidos" } \\
\text { (12) }\end{array}$ & $\begin{array}{l}\text { Reforma da } \\
\text { Igreja } \\
\text { (18) }\end{array}$ & - & - \\
\hline 1585 & $\begin{array}{l}\text { Profissáo de } \\
\text { Fé /Apresen- } \\
\text { taçáo } \\
\text { (3) }\end{array}$ & $\begin{array}{l}\text { Conversão dos infiéis } \\
\text { e "novamente conver- } \\
\text { tidos" } \\
(30)\end{array}$ & $\begin{array}{c}\text { Cristandade } \\
\text { de Sáo Tomé } \\
\text { (10) }\end{array}$ & $\begin{array}{l}\text { Reforma da } \\
\text { Igreja } \\
\text { (31) }\end{array}$ & $\begin{array}{l}\text { Reforma dos } \\
\text { costumes } \\
\quad(10)\end{array}$ \\
\hline 1592 & * & $\begin{array}{l}\text { Conversão dos infiéis } \\
\text { e "novamente conver- } \\
\text { tidos" } \\
\text { (14) }\end{array}$ & $\begin{array}{l}\text { Reforma da } \\
\text { Igreja } \\
\text { (16) }\end{array}$ & - & - \\
\hline 1606 & $\begin{array}{l}\text { Profissão de } \\
\text { Fé /Apresen- } \\
\text { tação } \\
(7)\end{array}$ & $\begin{array}{l}\text { Conversão dos infiéis } \\
\text { e "novamente conver- } \\
\text { tidos" } \\
\text { (33) }\end{array}$ & $\begin{array}{l}\text { Reforma da } \\
\text { Igreja } \\
\text { (76) }\end{array}$ & $\begin{array}{l}\text { Reforma dos } \\
\text { costumes } \\
\text { (33) }\end{array}$ & - \\
\hline
\end{tabular}

Notas:

- Náo houve açóes/decretos.

* Sem informação disponível. 
Uma das formas de identificar o provável impacto do Concílio de Trento é a própria alusão às determinaçóes tridentinas nos textos dos concílios provinciais de Goa. Se a presença de referências ao Concílio de Trento não implica necessariamente sua aplicação imediata no cotidiano do Arcebispado de Goa, não podemos negligenciar a constante menção às orientações tridentinas, o que elucida um substancial esforço de adequação da legislação eclesiástica da Índia portuguesa aos ditames do Concílio de Trento. Senão a expectativa de que aquela distante cristandade fosse modelada conforme as diretrizes instituídas em Trento, sob a orientação papal. Logo, estava em consonância com o imaginário imperial construído em torno da "Roma do Oriente", isto é, da cidade de Goa, concebida como enclave católico em terras asiáticas.

No Primeiro Concílio Provincial de Goa (Ação 1ª, "Decreto de protestação da fé"), revelou-se a expectativa de que estivesse em curso uma verdadeira atualização dos conteúdos da fé cristã no Oriente, por meio da introdução das mais recentes decisôes instituídas sob o auspício papal e do compromisso com a obediência irrestrita ao pontífice:

determinaram logo de manifestar e protestar a confissão de fé católica em que todos os verdadeiros cristãos convêm (o que há pouco foi instituído pelo santíssimo Pio IV, romano pontífice) e receber juntamente os decretos do ecumênico Concílio Tridentino, dando ao Romano Pontífice a obediência devida. ${ }^{25}$

Além da alusão à obediência ao pontífice, o trecho citado evidencia o rápido reconhecimento, no Oriente, da chamada Profissão de Fé tridentina (que o papa Pio IV, responsável por conduzir as últimas sessóes do Concílio de Trento, apresentou na constituição Iniunctum nobis, de 14 de novembro de 1564). ${ }^{26}$ Ressalta-se que a Professio fide foi discutida em maio de 1563 no Concílio de Trento, ocasião em que se estabeleceu que bispos, padres, abades e demais eclesiásticos prestassem um juramento, por meio da recitação de um breve texto, antes de serem providos em seus benefícios. Na verdade, a assembleia conciliar de Trento confiou ao Papado o trabalho de complementar tarefas náo concluídas, como a reforma dos catecismos e dos livros litúrgicos, em busca da uniformizaçấo ideológica e ritual. O papa Pio IV promulgou em 1564 um juramento mais amplo que, a seguir, fez parte das ediçôes dos decretos tridentinos. Tornou-se obrigatória a sua recitação não só para provimento de benefícios eclesiásticos, mas em diversas ocasióes. Prosperi explicou que a Professio fide era "tridentina" no sentido de resumir todas as doutrinas asseveradas pelo Concílio de Trento, mas também era "romana" em razão de declarar a obediência ao Papa e à Sé romana. ${ }^{27}$

\footnotetext{
${ }^{25}$ DHMPPO, v. 10, p. 337. A grafia foi atualizada.

${ }^{26}$ DENZINGER, Heinrich; HÜNERMANN, Peter. Compêndio dos símbolos, definiçôes e declaraçôes de fée e moral. São Paulo: Paulinas; Loyola, 2007. p. 465-466.

${ }^{27}$ PROSPERI, Adriano. El Concilio de Trento, op. cit. p. 90-91. O autor considera que a Professio fide era um marco na Era do Confessionalismo, ao estabelecer, de forma sintética, os conteúdos essenciais da doutrina ca-
} 
Em suma, a presença da Professio fide tridentina sugere a breve incorporação, na legislação do Arcebispado de Goa, dos esforços de uniformização doutrinária e litúrgica que remontaram ao Concílio de Trento - e que foram continuados pelo papado nos anos seguintes.

O arcebispo d. Gaspar de Leão convocou o Primeiro Concílio, mas recebeu a anuência do pontífice em relação ao seu pedido de resignação, de modo que fora substituído por $\mathrm{d}$. Jorge Themudo, ${ }^{28}$ que o sucedeu na condução dos trabalhos, a fim de concluir as atas do concílio. ${ }^{29}$ A carta de d. Jorge Themudo, redigida em 10 de junho de 1568, precedeu a divulgaçáo dos decretos do primeiro concílio, impressos naquele ano. $\mathrm{Na}$ carta, constam as seguintes palavras: "conforme ao sagrado e geral Concílio Tridentino, na sessão 24, Cap. 2º se convocou o ano passado de 67 a [sic] Concílio Provincial, que se celebrou nesta cidade de Goa”. ${ }^{30}$ Assim, o novo arcebispo associou a realização do Concílio Provincial ao cumprimento das orientaçôes tridentinas.

No que concerne à organização, o texto do Primeiro Concílio Provincial de Goa foi dividido em quatro açóes. A primeira consistiu no juramento de fé católica e de obediência à Igreja romana. A segunda parte tratou da difusão do catolicismo no Oriente e das relaçóes entre cristáos e não cristãos, explicitados em 47 decretos que refletiram a experiência de evangelização adquirida em espaços diretamente administrados pela Coroa portuguesa (como Goa, Baçaim, Damão e Diu) e em regióes fora do controle luso - como no Ceiláo, na Costa da Pescaria e em Travancor. A terceira parte abordou a reforma da Igreja e a quarta, a reforma dos costumes. ${ }^{31}$

As Constituiçôes do Arcebispado de Goa foram impressas em 1568, na capital do Estado da Índia, conforme a ordem de d. Gaspar de Leão, arcebispo e redator do texto. ${ }^{32}$ As Constituiçôes refletiram a experiência de d. Gaspar de Leão, que alegou só ter apresentado suas consideraçóes após três visitas realizadas no Arcebispado de Goa, com o intuito de perscrutar os desafios e as soluçóes para o exercício da vida cristã naquelas terras. Seu sucessor, o arcebispo d. Jorge Themudo, explicou que as Constituiçốes produzidas por d. Gaspar foram examinadas por ele e por outros prelados durante o Primeiro Concílio Provincial de Goa. ${ }^{33}$

No Prólogo das Constituiçôes, d. Gaspar de Leâo afirmou que cada vigário "usava do que mais lhe parecia” no passado; ${ }^{34}$ por essa razão seria fundamental a elaboração de leis

tólica, de modo que pudessem ser dirimidas as dúvidas em relação ao que se tratava de ortodoxia e de heresia. ${ }^{28}$ VENTURA, Ricardo. Conversão e conversabilidade: discursos da missão e do gentio na documentação do Padroado Português do Oriente (séc. XVI-XVII). Tese (doutorado em estudos de literatura e de cultura) Faculdade de Letras, Universidade de Lisboa, Lisboa, 2011. p.70.

${ }^{29}$ LOBO, Amaro Pinto (Ed.). Memória histórico-eclesiástica da Arquidiocese de Goa. Nova Goa: Tip. A Voz de São Francisco Xavier, 1933. p. 149.

${ }^{30}$ DHMPPO, v. 10, p. 334-335.

${ }^{31}$ REGO, Antônio da Silva. A liberdade religiosa e o I Concílio Provincial de Goa (1567). Memórias Academia das Ciências de Lisboa, Lisboa: Academia das Ciências, t. 10, p. 41-55, 1967.

${ }^{32}$ ABREU, Miguel Vicente de. Constituiçōes do Arcebispado de Goa. Ultramar. Nova Goa: s.n., 1878.

${ }_{33}^{3}$ DPHMPPO, v. 10, Constituiçóes do Arcebispado de Goa (1568), p. 485.

${ }^{34}$ DPHMPPO, v. 10, Constituiçóes do Arcebispado de Goa (1568), p. 484. 
que regulassem as atividades eclesiásticas no Oriente português. A respeito do impacto das decisôes tridentinas na formulação das leis, é elucidativo o comentário do arcebispo:

vieram a estas partes algumas determinaçóes do concílio sagrado que em Tridento se celebrava: nas quais vimos haverem-se de alterar muitas das constituiçóes já feitas. Pelo que sobrestivemos até o ano passado em que vieram as determinaçóes do dito concílio já acabadas (...) conforme às quais emendamos as constituições que tínhamos feito \& reduzimos neste volume, o qual oferecemos aos padres do primeiro santo concílio provincial, que este ano de 1567 foi celebrado (...) pedindo-lhe com humildade que o quisessem ver. ${ }^{35}$

Logo, o trecho indica o desejo de ajustar o texto das Constituiçóes de Goa ao que fora estabelecido no Concílio de Trento, pois d. Gaspar mencionou que "emendamos as constituições que tínhamos feito", ou seja, que os textos foram corrigidos para se adequar às determinações tridentinas. A escrita da versão final das Constituiçôes aguardou a chegada, a Goa, de um exemplar dos decretos tridentinos: "sobrestivemos até o ano passado em que vieram as determinaçōes do dito concílio já acabadas". De fato, o papa Pio V remeteu um volume dos decretos do Concílio de Trento a d. Gaspar de Leão. ${ }^{36}$

O Segundo Concílio foi celebrado em Goa, em 1575 - durante o governo de Antônio Moniz Barreto - , com atraso em relação ao interstício estabelecido para realizaçáo de sínodos provinciais, que deveria ser de três anos, conforme o cânon II da Sessão XXIV do Concílio de Trento. ${ }^{37}$ Em decorrência do falecimento de d. Jorge Themudo, o papa Gregório XIII determinou que d. Gaspar de Leão reassumisse a função de arcebispo de Goa. Por essa razão, d. Gaspar conduziu o Segundo Concílio e explicou o motivo do atraso: "Dado que pela obrigação, que temos do Sagrado Concílio Tridentino de celebrar Concílio Provincial cada três anos, pelos inconvenientes que houve não se pode celebrar depois do primeiro Concílio de Goa, o segundo". ${ }^{38}$

D. Gaspar de Leão explicou que náo foram preservados os trabalhos iniciados sob a condução de d. Jorge Themudo, de modo que os prelados foram novamente convocados para celebrar o concílio, cuja sessão inicial foi marcada para 12 de junho de 1575 . Nos primórdios do texto do Segundo Concílio, foram apresentados os propósitos de sua celebração, que consistiram na difusão da fé católica, na reforma dos costumes e "também para que no dito Concílio se ordenem decretos justos, e honestos, principalmente acerca da guarda, e observância dos santos decretos do divino Concílio Tridentino". ${ }^{39}$

\footnotetext{
${ }^{35}$ DPHMPPO, v. 10, p. 484-485, Prólogo das Constituiçóes do Arcebispado de Goa (1568).

36 "Pervenisse ad te litteras nostras una cum volumine decretorum sacri Concilii Tridentini libenter ex tuis litteris cognovimus. De injucto nobis officio". Documento de 7 de outubro de 1567, Bullarium Patronatus Portugalliae Regum in ecclesiis Africae, Asiae atque oceaniae. Lisboa: Typographia Nationali, 1870, t. I, p. 216. ${ }^{37}$ FEITLER, Bruno; SOUZA, Evergton Sales. Constituiçóes Primeiras do Arcebispado da Bahia, op. cit. p. 36.

${ }^{38}$ Archivo Portuguez-Oriental (doravante, APO), fasc. 4, p. 80.

${ }^{39}$ APO, fasc. 4, p. 83.
} 
Os decretos do Segundo Concílio dividem-se em três partes. A Ação $1^{\underline{a}}$ possui três decretos (um dos quais tratou do Símbolo da Fé), enquanto a Ação $2^{\underline{a}}$ reúne doze decretos que abordaram a difusão da fé e as relaçôes entre cristãos e não cristãos. Ao passo que a Ação $3^{3}$ foi organizada em dezoito decretos relativos ao culto divino, às igrejas e às obrigaçôes dos prelados.

Constata-se que as atas do segundo concílio tiveram uma dimensão muito menor do que a do texto do primeiro. Provavelmente, a conjuntura em que o Segundo Concílio de Goa foi realizado favoreceu o tratamento da matéria com maior celeridade, em virtude de os anos iniciais da década de 1570 terem sido anos instáveis no Estado da Índia, em razão dos cercos de Goa e de Chaul. O próprio arcebispado de Goa atravessou um período significativo de vacância entre o falecimento de d. Jorge Themudo e o retorno de d. Gaspar de Leão (entre 1571 a 1574), bem como após a morte deste último arcebispo e a nomeação de d. Frei Henrique de Távora e Brito (de 1576 a 1578), momentos em que a condução dos assuntos eclesiásticos coube ao cabido da Sé de Goa. ${ }^{40}$

$\mathrm{Na}$ Açáo 3 ${ }^{\mathrm{a}}$, decreto 17, mencionou-se que o Terceiro Concílio deveria ser celebrado em 1579, para se conformar ao que foi estabelecido no Concílio de Trento. ${ }^{41}$ Contudo, a reuniáo dos prelados só ocorreu em 1585, sob a condução do arcebispo d. Vicente da Fonseca, durante o governo do vice-rei d. Duarte de Meneses.

D. Vicente da Fonseca apresentou os mesmos motivos alegados nos concílios precedentes para celebração do terceiro: aumento da fé católica, reforma dos costumes dos fiéis e adequação às orientações do Concílio de Trento. Em obediência aos "antigos cânones, e decretos do sagrado Concílio Tridentino" ${ }^{\text {"42 }}$ foram convocados os prelados, superiores das ordens religiosas, membros do cabido e doutores.

$\mathrm{Na}$ Ação $1^{\underline{a}}$ aludiu-se à confissão de fé tridentina - "professando segundo a forma da Bula do Santíssimo Padre Pio IV" —, que deveria ser lida publicamente. No decreto 25 da Açáo $2^{a}$, recomendou-se a produçáo de um compêndio de doutrina cristá em português para o seu ensino na Índia, bem como sua tradução em línguas da terra onde houvesse atividade missionária. $\mathrm{O}$ mesmo deveria ser feito em relação à produção de um breve catecismo, "conforme ao catecismo Tridentino". ${ }^{43}$

O concílio foi dividido em cinco sessôes, de maneira que a Ação $1^{\underline{a}}$ possui três decretos. Os temas referentes à difusão do Evangelho e às relaçôes mantidas com a população não convertida foram definidos na Ação 2aㅡ, intitulada "Das cousas da conversão dos infiéis e Cristandade novamente convertida" e dotada de trinta decretos. Ao passo que a Açáa $3^{a}$ possuiu dez decretos apresentados pelo título: "Das cousas do Arcebispado de Angamale e Cristandade, que chamam de São Tomé, nas partes do Malabar”. Logo, as determinaçóes

\footnotetext{
${ }^{40}$ VENTURA, Ricardo. Conversáo e conversabilidade, op. cit. p. 87.

${ }^{41}$ APO, fasc. IV, p. 106, Segundo Concílio Provincial de Goa (1575).

${ }^{42}$ APO, fasc. IV, p. 109-110, Terceiro Concílio Provincial de Goa (1585).

${ }^{43}$ APO, fasc. IV, p.118 e 139, Terceiro Concílio Provincial de Goa (1585).
} 
contidas na Ação $3^{a}$ versaram sobre os cristãos da terra que não eram submetidos à Igreja Romana, os chamados "cristãos de São Tomé". A Ação 4ạ foi intitulada "Das cousas eclesiásticas e sua reformação e do Seminário dos Clérigos”, e dispôs de 31 decretos. E a Ação 5â, "De algumas cousas seculares, e sua reformação", reúne dez decretos.

O concílio de 1585 foi o primeiro em que os cristãos de São Tomé foram tratados de forma bastante detalhada, ${ }^{44} \mathrm{em}$ uma sessão dedicada exclusivamente aos desafios dos agentes católicos diante dessa comunidade de cristãos asiáticos. Dos oitenta decretos que compuseram o texto do Terceiro Concílio Provincial de Goa, dez trataram da cristandade de São Tomé e do arcebispo de Angamale. ${ }^{45}$

Na Ação 5ª̆, decreto 9oㅡㄹ determinou-se que o próximo concílio seria realizado em 1590. Porém, o Arcebispado de Goa obteve um privilégio, concedido pelo papa, que autorizou a celebração das reuniôes a cada cinco anos. Esta prerrogativa foi justificada em função da "distância, e navegaçáo dos Bispados dela". Recomendou-se que os trabalhos fossem iniciados até o mês de fevereiro de 1590, a fim de que o concílio terminasse até a monção de abril, de modo que os prelados pudessem retornar a suas igrejas. ${ }^{46}$

Contudo, mais uma vez, um concílio náo foi realizado na data prevista, pois o quarto foi celebrado apenas em 1592, por d. Mateus de Medina. Na cópia utilizada neste artigo não consta a transcrição da Ação 1a . Ao passo que a Ação 2a , apesar de não ter recebido um título, tratou da mesma matéria abordada nos concílios anteriores na sessão equivalente: a conversão dos infiéis, as relaçôes entre cristáos e não cristãos. Ao ser cotejado com o concílio precedente, o quarto concílio produziu um número bastante reduzido de decretos, pois a Ação $2^{\underline{a}}$ conteve onze decretos e a Ação $3^{a}$ (sobre os assuntos eclesiásticos) dispôs de dezesseis.

Por fim, o Quinto Concílio Provincial de Goa foi celebrado em 1606, sob a condução do arcebispo d. Aleixo de Meneses. A Ação 1a, composta por sete decretos, tratou da Profissão de Fé e da obediência à Igreja romana, conforme a bula do papa Pio IV (ação 1aㅗ decreto 50). ${ }^{47}$ A Ação $2^{a}$ intitulou-se "da conversão dos infiéis e boa administração da cristandade" e possui 33 decretos. A Açáo 3a ", "das cousas e governo eclesiástico", agrega 76 decretos e a Açâo $4^{a ̣}$ ("La reformação dos costumes da República Cristâ") possui 33 decretos. ${ }^{48}$

\footnotetext{
${ }^{44}$ A tentativa oficial de latinização da cristandade do Malabar (cristãos de São Tomé) foi adotada no Terceiro Concílio de Goa (em 1585), posteriormente, em 1599, o arcebispo d. Aleixo de Meneses convocou o Sínodo de Diamper para concretizar este intuito.

${ }^{45}$ NAZARETH, Casimiro C. de. Mitras lusitanas, op.cit.

${ }^{46}$ APO, fasc. IV, p. 182, Terceiro Concílio Provincial de Goa (1585).

${ }^{47}$ APO, fasc. IV, p. 203, Quinto Concílio Provincial de Goa (1606).

${ }^{48}$ WICKI, Josef. Die Konzilien der Kirchenprovinz Goa: 1567-1895. Annuarium Historiae Conciliorum. Augsburg, Walter Brandmuller Freiburg — Remigius Baumer, v. 12, p. 155-270, 1983.
} 


\section{A Reforma da Igreja no ultramar luso-asiático}

Até o momento foram analisados trechos das atas dos cinco concílios goeses que sugeriram a tentativa de incorporação dos decretos tridentinos. A seguir, pretende-se deslindar alguns dos ideais da Reforma Tridentina que marcaram a redação das atas dos concílios provinciais de Goa. Um dos aspectos que pretendemos destacar consiste na importância atribuída aos bispos na Reforma Católica e sua presença nas atas dos concílios de Goa.

Conforme Paiva, no contexto tridentino, houve a formulação de um modelo de bispo pastor das almas, inspirado em Cristo e sucessor dos apóstolos, residente em sua diocese. ${ }^{49}$ O bispo tridentino deveria ter bom comportamento, manter-se atento em relaçáo ao comportamento e à formação do clero, vigiar párocos e fiéis por meio de visitas pastorais, não negligenciar a prática da pregação e zelar para que os sacramentos fossem corretamente administrados. ${ }^{50}$ Com efeito, na sessão IV, capítulo IV do Concílio de Trento, determinou-se que os bispos visitem as igrejas, todas as vezes que for necessário. ${ }^{51}$ Ratificou-se a importância das visitas pastorais, bem como foi apresentado o seu propósito: "estabelecer a doutrina sã, e ortodoxa, excluídas as heresias, manter os bons costumes, emendar os maus". ${ }^{52}$

Nas Constituiçóes do Arcebispado de Goa (1568), no item que tratou da ação de bispos e do arcebispo, ${ }^{53}$ destacou-se o papel dos prelados como reformadores, como "pastores das almas", que acompanham o cotidiano dos fiéis. Essa concepção evidenciou-se no Terceiro Concílio Provincial de Goa (Ação 3ạ, decreto 5) ao ser instituída a relevância das visitas pastorais e a definição da sua regularidade:

A visitação dos Pastores eclesiásticos a suas ovelhas é muito necessária, e proveitosa (...) pelo que este Concílio encomenda aos Prelados visitem cada anos, ou ao menos cada dois anos todos os seus Bispados, como o Sagrado Concílio Tridentino lhes manda, e isso pessoalmente quando for possível (...) porque se em todas as partes as ovelhas folgam de ver e ouvir a seu próprio pastor, como os Santos dizem, e a experiência mostra, muito mais nestas partes da Índia, onde há tantos novamente convertidos, para quem muitas vezes é necessária a presença do Prelado..$^{54}$

O bispo ideal tridentino caracterizava-se por ser residente em sua diocese, para que não agisse "à maneira dos jornaleiros" que desamparam "os rebanhos, que lhes são cometidos",

\footnotetext{
${ }^{49}$ PAIVA, José Pedro. Os bispos de Portugal e do Império: 1495-1777. Coimbra: Imprensa da Universidade de Coimbra, 2006.

${ }^{50}$ Ibid., p.128-133.

${ }^{51}$ Sacrosanto, e Ecumênico Concílio de Trento, op. cit. t. 1, p. 167.

${ }^{52}$ Ibid., t. 2, p. 271. Sessão 23, capítulo III.

${ }^{53}$ DHMPPO, v. 10, p. 488.

${ }^{54}$ APO, fasc. 4, p. $155-156$.
} 
sem "guardar as suas ovelhas". Argumentou-se "que se não admite a desculpa do Pastor, quando o lobo come as ovelhas, e o Pastor o não sabe". ${ }^{55}$ Logo, o bispo idealizado tratou-se do pastor de almas, cujo protótipo é Jesus Cristo, o Bom Pastor, que zela por todas as almas. ${ }^{56}$

Como mencionamos, as autoridades do Arcebispado de Goa empreenderam esforços para tentar ajustar a legislação eclesiástica aos moldes da reforma religiosa estabelecidos em Trento. Por conseguinte, tais noçóes em torno do bispo ideal tridentino foram incorporadas às atas dos concílios de Goa. No quarto Concílio Provincial de Goa, reforçou-se a postura tridentina que restringiu a vacância dos prelados. ${ }^{57}$ No Quinto Concílio Provincial de Goa (Açáo 3ạ, decreto 43), determinou-se que os ordinários "tenham diante dos olhos o que o sagrado Concílio Tridentino dispóe acerca da residência dos beneficiados em suas igrejas", de modo que "não deem licença a cônegos, beneficiados confirmados com cura ou sem cura das almas para se ausentarem de seus benefícios". ${ }^{58}$

Uma das implicaçôes da reforma tridentina foi a valorização do papel de bispos e de párocos. ${ }^{59}$ No Quarto Concílio Provincial de Goa, Ação 3ª , decreto 1oㅡ, evidencia-se a tentativa de fortalecer o poder dos bispos diante do clero regular, no tocante à ordenaçáo sacerdotal:

O Sagrado Concílio Tridentino manda que os que se houverem de promover às ordens, sejam diligentemente examinados pelos Ordinários, ainda que sejam Regulares, e por que este Decreto se não guarda nesta Província no que toca aos ditos Regulares, porque os Ordinários cometem o exame deles a seus próprios Prelados, ordena e manda o Concílio daqui por diante se guarde em toda esta Província o que pelo sagrado Concílio Tridentino está mandado, e os Ordinários por si mesmo, e não por outrem, examinarão os Religiosos, que se houverem de ordenar..$^{60}$

No Quinto Concílio Provincial de Goa (Ação 3ả, decreto 11), há disposição similar ao estabelecer que - conforme o Concílio de Trento — os clérigos regulares fossem examinados pelos ordinários (ou por seus ministros e não pelos superiores de suas ordens religiosas), em caso de confissão ou ordenação sacerdotal. ${ }^{61} \mathrm{E}$, em circunstâncias como as comunhôes da Páscoa e nos castigos decorrentes das visitas pastorais, os professos das ordens militares, seculares e eclesiásticos deveriam se sujeitar ao ordinário, de modo que não pudessem reivindicar seus privilégios (decreto 22). ${ }^{62}$

\footnotetext{
${ }^{5}$ Sacrosanto, e Ecumênico Concílio de Trento, op. cit. t. 1, p. 159.

${ }^{56}$ Consultar a discussão em PAIVA, José Pedro. Os bispos de Portugal e do Império, op. cit. p. 128-132.

${ }^{57}$ APO, fasc. IV, p. 198.

${ }^{58}$ APO, fasc. IV, p. 242.

${ }^{59}$ VENARD, Marc. L'Église catholique. In: MAYEUR et al. (Org.). Histoire du christianisme. Paris: Desclée, 1992. v. 8; PAIVA, José Pedro. Os bispos de Portugal e do Império, op. cit.

${ }^{60}$ APO, fasc. 4, p. 194.

${ }^{61}$ APO, fasc. 4, p. 228.

${ }^{62}$ APO, fasc. 4, p. 232.
} 
Com efeito, a primazia do ordinário foi afirmada de forma notória nos decretos do Concílio de Trento, nas constituiçôes do Arcebispado de Goa e nas atas dos concílios locais. Porém, cabe ressaltar que na prática cotidiana de Goa foram intensas as disputas entre o poder episcopal e o clero regular, em busca da reafirmação de poderes ${ }^{63} \mathrm{Em}$ suma, se o protagonismo dos bispos como agentes da reforma (espiritual e dos costumes) foi confirmado precocemente nas atas dos concílios de Goa, a afirmação concreta da preeminência do ordinário foi construída, de forma conflitiva, ao longo de ao menos duas centúrias. ${ }^{64}$

A tensão entre a norma e a prática também pode ser considerada ao tratarmos de outro aspecto central associado à Reforma Católica: a formação do clero. A respeito do preparo dos sacerdotes, no decreto 5, Açáo $3^{\text {a }}$ do Primeiro Concílio Provincial de Goa, determinou-se que o clero regular deveria oferecer liçôes de Sagradas Escrituras em seus conventos, "por assim o Sagrado Concílio Tridentino o ordenar, e nestas partes" da Índia "não haver quem esta santa obra possa cumprir". No Terceiro Concílio Provincial, a reforma do clero e os assuntos eclesiásticos foram tratados na Ação $4^{\mathrm{a}}$, com destaque para o primeiro decreto, que determinou a criação de seminários nas dioceses da regiấo, a fim de se ajustar às orientaçóes tridentinas. $\mathrm{O}$ texto ponderou que talvez não fosse possível concretizar integralmente o que foi estabelecido no Concílio de Trento, pois, por exemplo, algumas dioceses do Oriente náo dispunham de seus próprios seminários. Nesse sentido, o decreto orientou para uma adequação à realidade, isto é, em circunstâncias concretas em que não havia seminários em todos os bispados. Assim, determinou-se que fosse criado ao menos um seminário na cidade de Goa, para o preparo dos moços de todos os bispados. Os bispos deveriam enviar, para Goa, "assim filhos de portugueses, como dos naturais da terra". ${ }^{65}$

Os decretos dos concílios celebrados em Goa incorporaram, em essência, as diretrizes tridentinas. Embora trechos das atas revelem que, em algumas circunstâncias, tal incorporação tinha, sobretudo, um caráter modelar, idealizado. Como mencionamos, os decretos apresentaram a necessidade de serem criados seminários nas dioceses do império luso-oriental, enquanto as instituiçóes existentes - como o Seminário da Santa Fé, de Cranganor, Reis Magos, Vaipicota e outros situados na Província do Norte — eram administradas pelas ordens religiosas. O que não se ajustava plenamente à tônica do Concílio de Trento que foi reforçar o papel dos ordinários na condução da reforma, o que estimulou a criação de seminários sob a administração direta dos bispos. Porém, a construção do primeiro seminário diocesano na Índia começou apenas em 1606 e foi estabelecido em Rachol. ${ }^{66}$

\footnotetext{
${ }^{63}$ Xavier analisou os desafios encontrados pelos bispos, em função da influência exercida pelo clero regular na administração das paróquias de Salsete e Bardez. XAVIER, Ângela Barreto. A invenção de Goa, op. cit. p. $158-161$.

${ }^{64}$ FARIA, Patricia Souza de. A conquista das almas do Oriente, op. cit. p. 238.

${ }^{65}$ APO, fasc. 4, p. 152-153.

${ }^{66}$ MELO, Carlos Mercês de, SJ. The recruitment and the formation of the native clergy in India: $16^{\text {th }}-19^{\text {th }}$. Lisboa: Agência Geral do Ultramar, 1955.
} 
Uma última consideração sobre a essência da Reforma Tridentina (e suas reverberaçóes em Goa) é avaliar em que medida as orientaçôes adotadas naquela época representaram uma efetiva inovação. Podemos considerar que procedimentos utilizados em antigas conjunturas históricas de reforma da Igreja foram retomados na Reforma Tridentina, como o controle sobre os fiéis por meio das redes de paróquias. ${ }^{67}$ Tais procedimentos tentaram ser aplicados em Goa. Ademais, o Concílio de Trento, em diversos aspectos, repetiu as antigas recomendaçôes destinadas a empreender a reforma da Igreja e dos fiéis, pois os bispos e os párocos deveriam pregar aos moradores da região que lhes competiam, residir entre eles e acompanhar o cumprimento das obrigaçóes sacramentais.

Adiciona-se que, em conjunturas anteriores ao Concílio de Trento, a ideia de reforma foi associada à vontade de regresso às origens. ${ }^{68}$ No século XVI, a percepção das novidades introduzidas pelo Concílio de Trento pôde ser compreendida, na Europa, como a restauração do antigo, isto é, uma reformatio da forma primitiva de cristianismo. Entre a Igreja Primitiva e a reformatio conduzida pelos bispos tridentinos teria ocorrido um período de decadência, isto é, uma de-formatio. ${ }^{69}$

Em Goa, os prelados reunidos no Primeiro Concílio Provincial perceberam-se como restauradores de um cristianismo arcaico pregado pelo apóstolo São Tomé na Índia (conforme várias tradiçôes afirmavam), mas cuja mensagem teria se degenerado (deformatio) e propiciado a proliferaçáo de heresias (como era entendida a doutrina da Igreja cristá local, dos cristãos de São Tomé, frequentemente associados à heresia de Nestório), além de diversas idolatrias asiáticas. A retórica presente na parte inicial do texto do Primeiro Concílio Provincial de Goa anunciou o desejo de promover a reformatio, ao superar a degeneração do cristianismo existente na Índia. Esse procedimento de reformatio era entendido pelos eclesiásticos como o ato de "desterrar a superstição", o que coincidia com o momento em que os reis de Portugal expandiram suas conquistas até o Oriente, o que teria favorecido a difusão do catolicismo na Ásia. No texto do Primeiro Concílio lê-se que, em decorrência "do muito aumento da República Cristã", propiciada pela expansão lusa, "foi necessário fazer-se esta

\footnotetext{
${ }^{67}$ VENARD, Marc. L'Église catholique, op. cit.; FARIA, Patricia Souza de. A conversão das almas do Oriente, op. cit.

${ }^{68}$ Ibid.; VAUCHEZ, A. A espiritualidade da Idade Média Ocidental: séculos VIII-XIII. Lisboa: Editorial Estampa, 1995; O'MALLEY, John. Trent and all, op. cit. p. 16-17; PROSPERI, Adriano. El Concilio de Trento, op. cit. Por exemplo, os reformadores do século XI consideravam que a renovação representaria nutrir-se do passado, o que se coadunava com a perspectiva de Gregório VII. Em determinadas conjunturas de reforma da Igreja, como a Gregoriana (que forneceu alguns dos parâmetros de reformas posteriores), a noção de reforma representou o reviver do estudo do direito canônico. A reforma (reformatio) foi concebida como retomada da disciplina antiga, que era entendida como mais bem formulada nos cânones antigos da Igreja. Logo, preconizou-se uma reforma pautada na disciplina, em práticas que se ajustavam às normas instituídas, pelo direito instituído pela Igreja.

${ }^{69}$ PROSPERI, Adriano. El Concilio de Trento, op. cit. p. 102.
} 
congregação de bispos, a qual foi a primeira que nesta província, pela bondade de Deus, se fez desde o tempo do bem-aventurado S. Thomé, Apóstolo das Índias". ${ }^{70}$

Portanto, na Primeira Ação - Decreto de protestação da fé, o Primeiro Concílio Provincial de Goa foi apresentado como o primeiro concílio realizado na Índia desde os tempos do apostolado de São Tomé, ${ }^{71}$ ou seja, estabelecia-se o vínculo entre as imaginadas assembleias de cristãos na época de um cristianismo primitivo difundido na Índia com o cristianismo "reformado" do período da conquista lusa e da Reforma Tridentina.

Acerca dos cristãos de São Tomé, foram realizados esforços a fim de que passassem à obediência da Igreja Romana e, por conseguinte, abandonassem o que os prelados do Arcebispado de Goa compreendiam como heresias. ${ }^{72}$ Além da expectativa de "regenerar" a cristandade de São Tomé, os agentes eclesiásticos legislaram em busca de instituir as normas para lidar com as populaçóes formadas por cristãos "novamente convertidos", portanto, neófitos que viviam nas proximidades de reinos islâmicos e de demais comunidades não cristãs.

\section{"Conforme os cânones antigos"}

A Ação $2^{a}$ contida nas atas dos concílios provinciais de Goa tratou da conversão dos gentios e dos infiéis, bem como dos cristáos neófitos. Os decretos foram introduzidos pela expressão: "Conformando-se (...) com os Cânones antigos". As bases dos decretos da Ação $2^{2}$ não se inspiram necessariamente no Concílio de Trento, mas em leis mais antigas, no "direito canônico" e em tradiçóes jurídicas que — desde o medievo — normatizaram as relações entre cristãos e não cristãos (judeus e muçulmanos) na Península Ibérica. Além deste conjunto de referências, foram significativas as práticas legislativas desenvolvidas no Oriente português (sobretudo entre as décadas de 1540 e 1560, isto é, entre o reinado de d. João III e a celebraçáo do Primeiro Concílio em Goa).

Sobre o primeiro grande conjunto de referências (as leis adotadas na Península Ibérica), a historiografia atestou as homologias entre as medidas adotadas em Portugal para normatizar as relaçôes sociais entre cristãos, judeus e muçulmanos e as aplicadas posteriormente em Goa (para tratar de cristãos e não cristãos). Destacam-se as interpretaçôes de Thomaz e de Xavier, que divergem em alguns aspectos. ${ }^{73}$ Em um contundente estudo, Xavier de-

\footnotetext{
${ }^{70}$ DHMPPO, v. 10, p. 337.

${ }^{71}$ Diversas tradiçóes propagaram a ideia de que o apóstolo Tomé teria partido para a Índia, região que terá evangelizado, e favorecido a criação das primeiras comunidades cristãs naquela localidade. THOMAZ, Luiz Filipe. A lenda de São Tomé Apóstolo e a expansão portuguesa. Lusitânia Sacra, v. 3, p. 349-388, 1991.

${ }^{72}$ CUNHA, João Teles e. De Diamper a Mattanchery: caminhos e encruzilhadas da Igreja Malabar e católica na Índia. Os primeiros tempos (1599-1624). Anais de História d'além-mar, Lisboa, v. 5, p. 283-368, 2004.

${ }^{73}$ Thomaz postulou que a experiência jurídica portuguesa no tratamento das comunidades muçulmanas e judias teria servido de parâmetro para modelar as ações adotadas em Goa. Destacou a dimensão da legislação medieval lusa caracterizada pela autonomia jurídica de tais comunidades. Consideramos que a interpretação
} 
monstrou como as atitudes da Coroa e dos agentes portugueses em relação às populaçôes dos espaços coloniais tiveram como parâmetro a experiência, desenvolvida no Reino, em relação às populaçôes judaicas e conversas. ${ }^{74}$

A essência da normativa secular e eclesiástica sobre judeus e mouros desenvolvida na Península Ibérica, desde a Alta Idade Média, ${ }^{75}$ tentou restringir os vínculos sociais entre cristãos e judeus, bem como as situaçôes que favorecessem o exercício do poder, o usufruto de melhores condiçôes econômicas e de prestígio pelos últimos — o que explica a profusão de decretos que impediram judeus, e depois também muçulmanos, de serem proprietários de escravos cristãos e de ocuparem cargos públicos, por exemplo. ${ }^{76}$ Os judeus foram proibidos de se casar com cristãs, e os filhos oriundos de tais uniôes deveriam ser batizados na fé católica. No $4^{\circ}$ Concílio de Toledo (631-636), determinou-se a retirada compulsória de filhos que estivessem sob os cuidados de pais judeus, para que fossem educados por cristãos. ${ }^{77}$ No século VII, obrigou-se o judeu a escolher entre se converter ao catolicismo ou abandonar o reino. Em suma, tais normas foram repetidas nos concílios posteriores celebrados na Península Ibérica, ao longo da Baixa Idade Média, como no Terceiro (1179) e no Quarto (1215) Concílios de Latrão (1215), em que se reforçou o papel dos sinais exteriores destinados a distinguir muçulmanos e judeus dos cristãos. ${ }^{78}$

As medidas destinadas a favorecer os cristãos permearam os textos de antigas coletâneas, como nas coleçôes do Corpus Iuris Canonici, em que se proíbe a entrega de cargos públicos aos judeus, o que é possível identificar no Decreto de Graciano (1140-1150) e nas Decretais de Gregório IX ou Liber Extra (1234). ${ }^{79}$ Os sínodos celebrados em Portugal nos séculos XIV e XV mantiveram tais orientaçóes. ${ }^{80}$ No tocante ao direito régio, cabe destacar que as Ordenações Afonsinas asseveraram o direito preexistente e a subalternização de muçulmanos e

oferecida por Xavier se coaduna, com mais precisão, com o contexto das décadas de 1540 a 1560, em Goa. Xavier propóe que os modelos buscados no reino (e aplicados em Goa) foram, de fato, os referentes ao tratamento jurídico de judeus e conversos. Porém, a autora destacou que a conjuntura posterior à década de 1530 impôs uma configuraçấo político-jurídica que se afastou da pluralidade dos ordenamentos, da autonomia jurídica e religiosa das distintas comunidades vigente no medievo ibérico, para se aproximar de um esforço sistemático de homogeneização do direito e da religião. THOMAZ, Luiz Filipe. De Ceuta a Timor. Lisboa: Difel, 1998; XAVIER, Ângela Barreto. $A$ invenção de Goa: poder imperial e conversóes culturais nos séculos XVI e XVII. 2003. Tese (doutorado em história) — Instituto Universitário Europeu, Florença, 2003. p. 80-81.

${ }^{74}$ Nesse sentido, é fundamental o estudo de XAVIER, Ângela Barreto. De converso a novamente convertido: identidade política e alteridade no reino e no império. Cultura, v. 22, p. 245-274, 2006.

${ }^{75}$ FERREIRA, Joaquim de Assunção. Estatuto jurídico dos judeus e mouros na Idade Média portuguesa. Lisboa: Universidade Católica, 2006.

${ }^{76}$ SANCOVSKY, Renata Rozental. Inimigos da fé: judeus, conversos e judaizantes na Península Ibérica. Séc. VII. Rio de Janeiro: Imprinta Express, 2010. p. 43-164.

${ }^{77}$ FERREIRA, Joaquim de Assunção. Estatuto jurídico dos judeus e mouros na Idade Média portuguesa, op. cit. p. 87.

${ }^{78}$ Ibid., p.146.

79 FIGUERÔA-REGO, João. A honra alheia por um fio: os estatutos de limpeza de sangue nos espaços de expressão ibérica (sécs. XVI-XVIII). Lisboa: Fundação Calouste Gulbenkian; FCT, 2011. p. 39.

${ }^{80}$ FERREIRA, Joaquim de Assunção. Estatuto jurídico dos judeus e mouros na Idade Média portuguesa, op. cit. 
judeus. ${ }^{81}$ Algumas determinaçôes das Ordenaçôes Manuelinas que regularam a relação entre cristãos e mouros tiveram apoio em decisóes de concílios, o que evidencia a interpenetração do direito canônico e do direito civil. ${ }^{82}$

O segundo conjunto de referências que inspiraram a redaçáo da Ação $2^{\mathrm{a}}$ dos concílios de Goa consiste na legislação adotada, na Índia, em torno de 1540 a 1560. Os responsáveis pela formulação de tais leis foram tanto as autoridades civis quantos as eclesiásticas, com destaque para os alvarás régios e as determinaçôes de vice-reis do Estado da Índia. ${ }^{83}$

Como já foi referido, as leis a favor da cristianização adotadas em Goa revelam similitudes com a normativa sobre judeus e mouros aplicada na Península Ibérica. Em síntese, as leis destinadas à cristianização de Goa anteriores a 1567 tiveram algumas orientaçôes centrais que foram mantidas nas atas do Primeiro Concílio Provincial e nas dos concílios seguintes. Uma das orientações foi a concessão de privilégios aos convertidos (como o acesso a cargos no Estado da Índia, que se tornaram proibidos aos não cristãos) e em formas de propiciar a primazia social e econômica dos cristãos sobre os demais grupos. Em 1545, o governador do Estado da Índia, Martim Afonso de Sousa, determinou que os brâmanes estavam impedidos de ocupar ofícios da Coroa. ${ }^{84} \mathrm{Em}$ 1557, uma determinação régia proibiu a ocupaçáo de ofícios da fazenda e da justiça por brâmanes, para que todos fossem ocupados por cristáos. ${ }^{85}$ Reitera-se a decisão em 23 de março de 1559, por ordem de d. Sebastião. ${ }^{86}$

Proibiçôes similares encontram-se nas atas dos concílios de Goa. O Primeiro Concílio ${ }^{87}$ impediu a ocupação de cargos por "infiéis" e que funcionários da Coroa se servissem deles. No Quarto Concílio, proibiu-se que cristãos usassem feitor gentio ou infiel, em razão dos riscos decorrentes de "estreita amizade" e do prejuízo à Coroa, por causa dos ganhos que ficam em posse dos gentios. ${ }^{88}$

Tal como na normativa medieval ibérica, as leis adotadas em Goa entre as décadas de 1540 e 1560 e as atas dos concílios provinciais concederam grande atenção à posse de escravos. D. João III determinou que todo escravo de senhor gentio ou mouro que se convertesse ao cristianismo poderia adquirir a liberdade.$^{89}$ Em 1557, o vice-rei Francisco Barreto passou uma provisão para que os escravos de senhores mouros ou gentios, que se convertessem ao cristianismo, fossem comprados por um proprietário cristấo. ${ }^{90}$ Em 1559, d. Sebastiáo deter-

\footnotetext{
${ }^{81}$ FIGUERÔA-REGO, João. A honra alheia por um fio, op. cit, p. 33.

${ }^{82}$ FERREIRA, Joaquim de Assunção. Estatuto jurídico dos judeus e mouros na Idade Média portuguesa, op. cit.

${ }^{83}$ Estes documentos foram agrupados no Códice "Leis a favor da Cristandade", sob guarda do Arquivo Histórico de Goa e publicados por Antônio da Silva Rego (DHMPPO).

${ }^{84}$ MENDONÇA, Délio de. Conversions and citizenry: Goa under Portugal. 1510-1610. Nova Delhi: Concept Pub., 2002. p. 179.

${ }^{85}$ DHMPPO, v. 7, doc. 46, p. 215.

${ }^{86}$ DHMPPO, v. 7, doc. 60, p. 273.

${ }^{87}$ As citaçóes dos decretos desta parte do artigo referem-se à Ação 2a

${ }^{88}$ APO, fasc. 4, p. 192-193.

${ }^{89}$ DHMPPO, v. 7, doc. 43, p. 207-211.

${ }^{90} \mathrm{DHMPPO}$, v. 7, doc. 45, p. 214; a legislação sobre o tema sofreu várias alteraçôes, ver: doc. 50, p. 226.
} 
minou que todo mercador ou estrangeiro judeu, mouro ou gentio, cujo escravo se convertesse ao cristianismo, deveria vendê-lo a cristãos. ${ }^{91}$ No tocante aos concílios, foi estabelecido que, "Conformando-se (...) com os Cânones antigos", nenhum infiel tivesse escravo cristão, e se o cativo se tornasse católico, deveria ser alforriado (Primeiro Concílio, decreto 16). ${ }^{92}$ No Terceiro Concílio foi estabelecido que essa determinação do Primeiro Concílio, pautada no "direito comum", fosse estendida aos escravos cristáos de Malaca. ${ }^{93}$ O Quinto Concílio determinou que o escravo de um infiel que se convertesse seria retirado da posse de seu dono, por no máximo doze cruzados, "conforme os Sagrados Cânones".94

As medidas presentes na legislação adotada na Índia portuguesa (e posteriormente nos concílios) versaram sobre a expulsão dos grupos considerados entraves à conversão, como os brâmanes, caso da provisão do vice-rei de 2 de abril de $1560 .{ }^{55}$ No Primeiro Concílio (decreto 6), estabeleceu-se a expulsão de todos que "têm por ofício sustentar suas falsas religiôes", como os cacizes dos mouros, iogues, feiticeiros, grous, brâmanes, parbus (Primeiro Concílio, Ação 2ạ, decreto 6). Tentou-se criar uma topografia da exclusão, por meio de bairros ou moradias exclusivas para não cristãos. ${ }^{96}$ Estabeleceu-se que cristãos só arrendassem terras a cristãos ${ }^{97}$ (Primeiro Concílio, decreto 15) e não alugassem casa em povoação de cristáos a mouros. Outra preocupação era impedir a coabitação de fiéis com infiéis (Terceiro Concílio, decreto 14 , reiterado no Quarto Concílio). ${ }^{98}$ Outra forma de separaçáo, bastante adotada na legislação medieval ibérica, era a distinção exterior de cristãos e não cristáos. $\mathrm{Na}$ Índia, católicos não deveriam portar sinais exteriores e trajes típicos de mouros, gentios ou de judeus. Analogamente, nenhum gentio ou infiel deveria utilizar "vestido de cristáo". ${ }^{99}$ Foi abundante a legislação que tratou da controvérsia em torno da exibição de sinais exteriores que indicassem o pertencimento a grupos sociais e seitas religiosas.

Por fim, cabe considerar que a legislação proibiu o culto público do islamismo, do gentilismo, além de determinar a destruição dos templos locais, em Goa. ${ }^{100}$ Interditou a realizaçâo de rituais (hindus e muçulmanos) celebrados em ocasióes como nascimento, morte e casamento - o que foi bastante expressivo durante o governo de d. Pedro de Mascarenhas, em 1554 e 1555. Porém, o governador Francisco Barreto (1555-1558), diante da pressão exercida pela população local não convertida, suspendeu os decretos promulgados anteriormente

\footnotetext{
${ }^{91}$ DHMPPO, v. 7, doc. 61, p. 275-276,

${ }^{92}$ DHMPPO, v. 10, p. 351.

${ }^{93}$ APO, fasc. 4, p. 135.

${ }^{94}$ APO, fasc. 4, p. 212-213.

${ }^{95}$ DHMPPO, v. 8, doc. 10, p. 28.

${ }^{96}$ DHMPPO, v. 10, p. 357 (Primeiro Concílio, Ação 2ª decreto 25).

${ }^{97} \mathrm{DHMPPO}$, v. 10, p. 351 (Primeiro Concílio, Ação 2ạ, decreto 15).

${ }^{98}$ APO, fasc. 4, p. 130-131, 191.

${ }^{99}$ DHMPPO, v. 7, doc. 46, p. 216.

${ }^{100}$ DHMPPO, v. 7, doc. 64, p. 284.
} 
que haviam proibido o sati, sacrifício ritual de viúvas indianas. ${ }^{101}$ Poucos anos depois, o vice-rei d. Constantino de Bragança proibiu a prática do sati, por meio do alvará de 30 de junho de 1560. A pessoa responsável por favorecer este ritual perderia toda a fazenda e se tornaria cativa de quem a denunciasse. ${ }^{102}$

Os concílios provinciais tentaram impedir os rituais supracitados. O Segundo Concílio destacou que: "Entre muitos abusos, que estes gentios tem, é um que falecendo o marido, a mulher raspa a cabeça em sinal que já se não pode casar, de que nasce não se converter a viúva facilmente". Contrariamente, o decreto 10 autoriza o casamento de tais viúvas (decreto 10). ${ }^{103}$ No Terceiro Concílio (decreto 11), afirma-se que o decreto anunciado no concílio anterior não era cumprido, por isto a determinação foi reiterada. ${ }^{104}$ No Quinto Concílio (decreto 12), impediu-se que as mulheres cristâs e as gentias nascidas na Índia, até cinquenta anos de idade, raspassem a cabeça após a morte do marido. ${ }^{105}$

Cabe notar o dinâmico processo de instituição de tais normas, visto que tais leis não foram adotadas imediatamente pelos vice-reis e governadores do Estado da Índia, que por vezes procrastinavam a divulgação das determinaçôes régias em Goa ${ }^{106}$ ou adotavam procedimentos favoráveis aos grupos nativos não convertidos. Tornou-se possível acompanhar o grau de divergência entre os agentes portugueses, pois os religiosos relataram aos monarcas em que medida os governantes do Estado da Índia deixavam de aplicar as leis destinadas à cristianização sistemática. Os vice-reis, por sua vez, consideraram as pressōes das populaçôes locais atingidas por tal legislação (que propiciou impactos sobre a vida econômica em Goa, ao estimular fugas e abandono de atividades produtivas por populaçóes nativas que optaram por não se converter). Logo, podemos considerar que as leis destinadas a favorecer a cristianização — criadas entre as décadas de 1540 e 1560 — resultaram deste dinâmico e conflituoso processo de instituição das normas, caracterizado por processos de imposição oriundos do "centro" (da Coroa, do Arcebispado), mas também resultado de negociaçôes, pois foi impactante o peso das pressóes exercidas pelas populaçôes locais na revisão das normas instituídas. Raciocínio análogo cabe aos textos dos concílios provinciais de Goa, visto que a constante repetição de normas instituídas nas reuniôes precedentes indica os intensos desafios associados à efetivação dos ideais de reforma postulados pelos prelados do Arcebispado de Goa.

\footnotetext{
${ }^{101}$ MENDONÇA, Délio de. Conversions and citizenry, op. cit. p. 257-259.

${ }^{102}$ DHMPPO, v. 8, doc. 14, p. 40.

${ }^{103}$ APO, fasc. 4, p. 97.

${ }^{104}$ APO, fasc. 4, p. 128-129.

${ }^{105}$ APO, fasc. 4, p. 211.

106 WICKI, J. Documenta Indica. Roma: M.H.S.I., 1948-1988. v. 6, doc. 24, p. 122-123.
} 


\section{Considerações finais}

A leitura do conjunto das atas dos concílios provinciais de Goa sugere a presença das diretrizes essenciais que caracterizaram a reforma tridentina, como o fortalecimento do papel dos bispos e dos párocos, a importância atribuída à formação sacerdotal e a uniformização litúrgico-ritual. Estas considerações revelam um notável esforço de ajustamento dos decretos dos concílios provinciais de Goa às orientaçóes tridentinas, o que se destaca se compararmos à cronologia mais tardia associada às iniciativas legislativas adotadas pelos prelados que atuaram na porção atlântica do império, como na América portuguesa.

Além da incorporação da "novidade" (representada pelos decretos tridentinos), as atas dos concílios de Goa inspiraram-se em tradiçôes e leis instituídas antes da celebração do Concílio de Trento. Nesse aspecto, os decretos da Ação $2^{a}$ tiveram como referência o conjunto de leis que pretendeu definir as relaçôes sociais entre cristãos e não cristãos na Península Ibérica. ${ }^{107}$ Porém, não se tratou de sua mera reprodução nas atas dos concílios de Goa, visto que os contextos históricos e culturais distintos impuseram alguns ajustamentos nas leis aplicadas previamente na Península Ibérica. Similarmente, a própria legislação adotada na Índia sofreu inflexôes (por vezes sutis, por vezes abruptas) em decorrência das distintas conjunturas e das pressóes exercidas pelos agentes locais.

Outro aspecto a destacar é que os decretos dos concílios provinciais de Goa refletem a necessidade de adequação dos modelos formulados no "centro" (no Reino de Portugal, em Trento) às realidades encontradas no interior do esparso e heterogêneo Estado da Índia. Nesse sentido, as determinaçóes foram ajustadas aos diferentes estatutos dos povos que viveram nas regióes sob o controle português, bem como nas áreas livres da influência lusa. A legislação eclesiástica de Goa precisou contemplar os distintos níveis de vassalagem e de vínculos dos povos locais com a Coroa lusa. Destarte, os privilégios ou restriçóes impostas pela lei precisavam se moldar: ao súdito cristáo habitante de Goa, ao "infiel" que se relacionava com agentes portugueses (em terras lusas), às especificidades das sociedades locais (estabelecidas em Goa, Malaca, Ormuz e demais espaços do império luso-asiático), à condição de neófito católico ou de cristão de São Tomé.

Em linhas gerais, a análise das atas dos cinco concílios provinciais de Goa revela a constante referência aos decretos tridentinos, o que foi acompanhado do alegado esforço de ajustar a ação da Igreja em Goa aos modelos de reforma institucional e espiritual formulados no Velho Mundo. Tratava-se de tentar aproximar a distante e heteróclita cristandade goesa do ideal de uniformidade (ideológica e ritual) postulado no Concílio de Trento.

Artigo recebido em 31 de março de 2013 e aprovado em 15 de outubro de 2013.

*Agradeço o auxílio à pesquisa concedido pelo CNPq por meio do Edital Universal - 2012.

** Doutora em história pela Universidade Federal Fluminense, professora adjunta da Universidade Federal Rural do Rio de Janeiro. E-mail: patricia@carvano.com.br.

${ }^{107}$ Consultar as interpretaçóes já citadas, de autoria de Luiz Filipe Thomaz e Ângela Xavier: THOMAZ, Luiz Filipe. De Ceuta a Timor, op. cit.; XAVIER, Ângela Barreto. De converso a novamente convertido, op. cit. 